\title{
Complications Associated with Diabetes: A Case Study
}

\author{
Muhammad Daoud Butt ${ }^{1, *}$, Muhammad Khalid Tipu ${ }^{1}$, Iftikhar Malik ${ }^{2}$ and Yusra Habib Khan ${ }^{3}$ \\ ${ }^{I}$ Department of Pharmacy, Quaid-i-Azam University, Islamabad, Pakistan. \\ ${ }^{2}$ Federal Government Service Hospital Islamabad, Pakistan. \\ ${ }^{3}$ Descipline of Clinical Pharmacy, School of Pharmaceutical Sciences, University Sains Malaysia, 11800 Pulau Penang, Malaysia.
}

\begin{abstract}
Background: The current study has focused on the complications arising in a patient due to diabetes mellitus and how the patient's quality of life has been affected. The most feared complication of the disease is loss of lower limb due to infection and major cardiovascular complications.
\end{abstract}

Objectives: Management of a patient with diabetes and cardiovascular complication with history of tuberculosis is studied along with antimicrobial interventions for curing the ulcer and reducing risk of amputation. Cardiovascular complication, one of the co-morbidity of diabetes, was also managed.

Methods: After selection of the patient, consent from patient and approval from relevant authority were obtained, patient was kept under observation for a week.

Case Presentation: Patient was admitted with complaints of: shortness of breath, palpitation, exertional dyspnea and a spreading right shin discharging foot ulcer.

Conclusion: Patient was treated with antibiotics and ionotropic agent and indicated better rate of prognosis.

Keywords: Atrial fibrillation, congestive heart failure, diabetes mellitus, infection.

doi.org/10.21089/njhs.21.0043

\section{INTRODUCTION}

Diabetes mellitus (DM) is a lifelong metabolic disorder which affects the biochemical pathways and cycles that help the body to utilize energy. Diabetic neuropathy is a crucial complication that not only affects the quality of life but also increases the morbidity rate. Serious secondary complications like diabetic foot ulcer and heart failure can develop as a result of unrecognized symptoms of autonomic neuropathy. The most awful complication of diabetes mellitus is diabetic foot which results in loss of lower limb and a challenge to surgeons due to an association with sudden cardiorespiratory deaths during and after the surgery in DM patients, [1-3].

Another complication of acute metabolism associated with mortality includes diabetic ketoacidosis due to remarkable hyperglycemia and coma as the result of marked hypoglycemia.

*Address correspondence to this author at the Department of Pharmacy Quaid-i-Azam University, 45320-Islamabad, Pakistan.

Email: muhammaddaoud10@yahoo.com
In DM, the subsequent complications come together with "microvascular disease" and "macrovascular disease". Microvascular complications consist of retinopathy, nephropathy and neuropathy. The major macrovascular complications include aggravated cardiovascular disorder resulting in myocardial infarction and strokes. Patients with hypertension and diabetes mellitus have amplified possibility of evolving atrial fibrillation (AF). AF increases the risk of cardiovascular disorders, [4-6]. Knowing all these complications, self-care management could play a vital role in the prevention and prevalence of diabetic foot ulcer but these programs are needed to be more vigilant and versatile to have comprehensive approach on associated comorbidities $[7,8]$.

Diabetic ulcer foot usually leads to the amputation of the major part of limbs. Some new therapies could be an ideal approach for such patients; stem cell gives us a way to save patients limbs from major amputations. There are obvious advantages and disadvantages with every kind of treatment, but the best actual solution to the problem would be to control the microvascular and macrovascular complication that

www.njhsciences.com 
are associated with type $2 \mathrm{DM}$ and there is the need to standardize the medical therapy for the patients with such complications $[9,10]$.

South Asian migrants and their offspring who migrated to effluent western nations have higher prevalence rates of DM than the native population: Bangladesh-4.7-8.5\% (20042005; Rural), India-4.6-12.5\% (2007; Rural); Maldives-3.0$3.7 \%$ (2004), Nepal-19.5-9.5\% (2007), Pakistan-3.0-7.2\% (2002), Sri Lanka-11.5-10.3\% [11].

\section{CASE PRESENTATION}

A debilitated male patient 50 years previously diagnosed with type II DM along with the history of tuberculosis was admitted with the complaints of shortness of breath, palpitation and exertional dyspnea. Patient also had painful discharging ulcer on right shin which was spreading day by day. There is also a family history of cardiovascular complications. Physical examinations revealed clubbing of nail and edema of lower extremity. Initially patient was unaware of the fact that there was any prevailing cardiovascular complication. However, physician indicated that patient was showing signs of---actual symptom. Tuberculosis was ruled out after carrying out the diagnostic tests.

On examination, the overall general condition was poor with Pulse rate of $98 /$ minute, body temperature $100 \mathrm{~F}$ and B.P $110 / 70 \mathrm{~mm}$ of $\mathrm{Hg}$. Patient's ECG revealed atrial fibrillation while X-ray examination showed an increase in cardiothoracic ratio (CTR).

Initially patient's leg ulcer was examined and physician prescribed ceftriaxone $\left(3^{\text {rd }}\right.$ generation cephalosporin) after wound debridement and dressing. Blood Sugar level was measured to be $143 \mathrm{mg} / \mathrm{dl}$. After monitoring the patient for one day with various tests being performed, confirmed findings for congestive heart failure (CHF) with atrial fibrillation. For management of atrial fibrillation $/ \mathrm{CHF}$, the patient was given digoxin with warfarin. Patient was monitored at regular intervals as digoxin showed to increase the rate of mortality rate when given for complaints like CHF [12, 13].

\section{DISCUSSION}

DM causes greater degree of damage to nerves and vasculature. Patients with DM have nerve damage hence unable to feel any kind of trauma [14] and diabetic cardiomyopathy [15].

In present study the patient had spreading infectious ulcer on the shin of right leg. On day one of admission the major concern for physician was to deal with the patient's cardiovascular complication. As the patient was diabetic, physician continued the metformin to regulate blood sugar level as it has been reported to be the safest drug to control sugar level in CVS disorder, [16]. For the infection, physician prescribed ceftriaxone along with diclofenac sodium and cleared the infected wound from pus and applied duoderum dressing: a standard diabetic foot ulcers (DFU) dressing [17, 18]. Modern approach for treating the DFU includes the use of topical anhydrous silicon base containing pracaxi oil; this medication can be compounded and can be tailored according to the need of the patient [19].

On the second day the physician prescribed digoxin for $\mathrm{CHF}$ and atrial fibrillation and warfarin to prevent incidence of Thromboembolism as per recommendation [20].

On the third day of admission patient complained of three loose stools (might be beginning of toxicity of digoxin) without blood which would be the possible side effect of the antibiotic used. Patient was prescribed metronidazole I/V to control diarrhea but patient only needed supportive treatment as metronidazole is not for drug induced diarrhea. In drug induced diarrhea most appropriate supportive therapy is the use of probiotics [21].

On fourth day of admission the patients International Normalize Ratio (INR) raised to 6 therefore Warfarin was stopped. Patient was administered Vitamin B complex and salt free albumin for hypoalbuminemia to cover the toxicity of digoxin. As digoxin is highly protein bound drug and albumin was given to prevent toxicity [22].

Patient remained under observation for 6 days and vitals were normal but pulse rate was $92 /$ min showing tachycardia. On the sixth day, patient complained of dizziness and abdominal pain. Therefore patient was prescribed potassium chloride I/V to cover up digoxin toxicity . On the seventh day patient was feeling much better and laboratory findings indicated better prognosis. Patient was discharged with regular medication: captopril and carvedilol for cardiac problems and instructed to change wound dressing after 1 week.

Table 1. Laboratory Findings of the Patient.

\begin{tabular}{|c|c|c|}
\hline \multicolumn{3}{|c|}{ Blood Count } \\
\hline & Normal Range & Result \\
\hline WBC & $4-11.6 \times 103$ cells/ $\mu 1$ & $14.2 \times 103$ cells $/ \mu 1^{*}$ \\
\hline $\mathrm{Hb}$ & $11.5-16.4 \mathrm{~g} / \mathrm{dl}$ & $13.7 \mathrm{~g} / \mathrm{dl}$ \\
\hline $\mathrm{MCV}$ & $76-96 \mathrm{fl}$ & $85 \mathrm{fl}$ \\
\hline Platelet & $150-400 \times 100 / 1$ & $183 \times 100 \mathrm{cells} / 1$ \\
\hline \multicolumn{3}{|c|}{ Renal Profile } \\
\hline $\mathrm{Na}^{+}$ & $136-146 \mathrm{mmol} / \mathrm{l}$ & $141 \mathrm{mmol} / \mathrm{l}$ \\
\hline $\mathrm{K}^{+}$ & $3.5-5 \mathrm{mmol} / \mathrm{l}$ & $4.4 \mathrm{mmol} / \mathrm{l}$ \\
\hline Urea & $2.8-7.2 \mathrm{mmol} / \mathrm{l}$ & $4.1 \mathrm{mmol} / \mathrm{l}$ \\
\hline
\end{tabular}




\begin{tabular}{|c|c|c|}
\hline \multicolumn{3}{|c|}{ LFT (Recommended 3rd day Test) } \\
\hline T.Protein & $66-83 \mathrm{~g} / 1$ & $35 \mathrm{~g} / 1^{*}$ \\
\hline Albumin & $35-52 \mathrm{~g} / 1$ & $21 \mathrm{~g} / 1^{*}$ \\
\hline T.Bilirubin & $5-21 \mu \mathrm{mol} / 1$ & $25 \mu \mathrm{mol} / 1^{*}$ \\
\hline ALP & $40-150 \mathrm{U} / 1$ & $117 \mathrm{U} / 1$ \\
\hline ALT & $0-55 \mathrm{U} / 1$ & $41 \mathrm{U} / 1$ \\
\hline $\mathrm{CRP}(\mathrm{C}$ reactive Protein $)$ & $0.10 \mathrm{mg} / 1$ & $46 \mathrm{ml} / \mathrm{L}^{*}$ \\
\hline PT & $10-13.5 \mathrm{Sec}$ & $35 \sec ^{*}$ \\
\hline APTT & $26-42 \mathrm{sec}$ & $25 \mathrm{sec}$ \\
\hline INR & $<1.5$ & 1.1 \\
\hline \multicolumn{3}{|c|}{ Sugar Test } \\
\hline Blood Sugar & $<100 \mathrm{mg} / \mathrm{dl}$ & $143 \mathrm{mg} / \mathrm{dl} *$ \\
\hline \multicolumn{3}{|c|}{ MISC Test } \\
\hline $\mathrm{LDH}$ & $140 \mathrm{U} / \mathrm{L}$ & $589 \mathrm{U} / 1^{*}$ \\
\hline Folic Acid & 2.7 to $17.0 \mathrm{ng} / \mathrm{mL}$ & $1.84 \mathrm{ng} / \mathrm{ml}^{*}$ \\
\hline $\mathrm{X}$-ray & & CTR increased* \\
\hline ECG & & $\begin{array}{c}\text { Atrial Fibrillation } \\
\text { rapid Ventricular } \\
\text { response* }^{*}\end{array}$ \\
\hline
\end{tabular}

\begin{tabular}{|c|c|c|c|}
\hline \multicolumn{5}{|c|}{$6^{\text {th }}$ Day Medication } \\
\hline Potassium Salt & $4 \mathrm{mEq}(\mathrm{I} / \mathrm{V})$ & 6 th day & Once \\
\hline \multicolumn{4}{|c|}{ Discharged Medication } \\
\hline Captopril & $25 \mathrm{mg}$ & 2 weeks & OD \\
\hline Carvedilol & $12.5 \mathrm{mg}$ & 2 weeks & OD \\
\hline Metformin & $500 \mathrm{mg}$ & & OD \\
\hline
\end{tabular}

\section{ACKNOWLEDGEMENT}

Declared none.

\section{CONFLICT OF INTEREST}

Declared none.

\section{REFERENCES}

[1] Van Acker K, Bouhassira D, De Bacquer D, Weiss S, Matthys K, Raemen H, Mathieu C, Colin IM. Prevalence and impact on quality of life of peripheral neuropathy with or without neuropathic pain in type 1 and type 2 diabetic patients attending hospital outpatients clinics. Diabet. Metabol., 2009; 35(3): 206-13.

[2] Adriaanse MC, Drewes HW, van der Heide I, Struijs JN, Baan CA. The impact of comorbid chronic conditions on quality of life in type 2 diabetes patients. Quality of Life Res., 2016; 25(1): 175-82.

[3] Gregg EW, Sattar N, Ali MK. The changing face of diabetes complications. Lancet Diab. Endocrinol., 2016; 4(6): 537-47.

[4] Aksnes TA, Schmieder RE, Kjeldsen SE, Ghani S, Hua TA, Julius S. Impact of new-onset diabetes mellitus on development of atrial fibrillation and heart failure in high-risk hypertension (from the VALUE Trial). Am. J. Cardiol., 2008; 101(5): 634-8.

Table 2. Medication profile of patient during hospitalization.

\begin{tabular}{|c|c|c|c|}
\hline \multicolumn{4}{|c|}{$\mathbf{1}^{\text {st }}$ Day Medication } \\
\hline Drug & Strength & Duration & Frequency \\
\hline Ceftriaxone & $2 \mathrm{mg}(\mathrm{I} / \mathrm{V})$ & 1 st-7th day & OD \\
\hline Diclofenac & $75 \mathrm{mg} / 3 \mathrm{ml}(\mathrm{I} / \mathrm{V})$ & 1st day only & $\mathrm{BD}$ \\
\hline Metformin & $500 \mathrm{mg}$ & $\begin{array}{l}\text { 1st day- } \\
\text { onwards }\end{array}$ & OD \\
\hline Duoderum Dressing & & & \\
\hline \multicolumn{4}{|c|}{$2^{\text {nd }}$ Day Medication } \\
\hline Digoxin & $25 \mathrm{mg}$ & 2nd-7th day & OD \\
\hline Warfarin & $5 \mathrm{mg}$ & 2nd-3rd day & OD \\
\hline \multicolumn{4}{|c|}{$3^{\text {rd }}$ Day Medication } \\
\hline Metronidazole & $500 \mathrm{mg}(\mathrm{I} / \mathrm{V})$ & 3rd day & OD \\
\hline \multicolumn{4}{|c|}{$4^{\text {th }}$ Day Medication } \\
\hline Salt Free Albumin & $50 \mathrm{~g}(\mathrm{I} / \mathrm{V})$ & 4th day & Once \\
\hline Vitamin B Complex & & 4th-7th day & OD \\
\hline
\end{tabular}

[5] Staszewsky L, Cortesi L, Baviera M, Tettamanti M, Marzona I, Nobili A, Fortino I, Bortolotti A, Merlino L, Disertori M, Latini R. Diabetes mellitus as risk factor for atrial fibrillation hospitalization: Incidence and outcomes over nine years in a region of Northern Italy. Diab. Res. Clin. Prac., 2015; 109(3): 476-84.

[6] Goudis CA, Korantzopoulos P, Ntalas IV, Kallergis EM, Liu T, Ketikoglou DG. Diabetes mellitus and atrial fibrillation: Pathophysiological mechanisms and potential upstream therapies. Int. J. Cardiol., 2015; 184: 617-22.

[7] Bonner T, Foster M, Spears-Lanoix E. Type 2 diabetes-related foot care knowledge and foot self-care practice interventions in the United States: a systematic review of the literature. Diabetic Foot Ankle., 2016; 7: 29578.

[8] Heinrich E, Schaper NC, de Vries NK. Self-management interventions for type 2 diabetes: a systematic review. European Diab. Nurs., 2010; 7(2): 71-6.

[9] Constantin C, Constantin G, Sirbu M, Buzoianu C. Step by step treatment of diabetic foot-new treatment possibilities. J. Clin. Case Rep., 2016; 6(721): 2.

[10] American Diabetes Association. Standards of medical care for patients with diabetes mellitus. Puerto Rico. Health Sci. J., 2013; 20(2).

[11] Jayawardena R, Ranasinghe P, Byrne NM, Soares MJ, Katulanda P, Hills AP. Prevalence and trends of the diabetes epidemic in South 
Asia: a systematic review and meta-analysis. BMC Public Health, 2012; 12(1): 1.

[12] Allen LA, Fonarow GC, Simon DN, Thomas LE, Marzec LN, Pokorney SD, Gersh BJ, Go AS, Hylek EM, Kowey PR, Mahaffey KW. Digoxin use and subsequent outcomes among patients in a contemporary atrial fibrillation cohort. J. Am. Coll. Cardiol., 2015; 65(25): 2691-8.

[13] Washam JB, Stevens SR, Lokhnygina Y, Halperin JL, Breithardt G, Singer DE, Mahaffey KW, Hankey GJ, Berkowitz SD, Nessel CC, Fox KA. Digoxin use in patients with atrial fibrillation and adverse cardiovascular outcomes: a retrospective analysis of the rivaroxaban once daily oral direct factor xa inhibition compared with vitamin $\mathrm{K}$ antagonism for prevention of stroke and embolism trial in atrial fibrillation (ROCKET AF). Lancet. 2015; 385(9985): 2363-70.

[14] Brownlee M. Biochemistry and molecular cell biology of diabetic complications. Nature. 2001; 414(6865): 813-20.

[15] Isfort M, Stevens SC, Schaffer S, Jong CJ, Wold LE. Metabolic dysfunction in diabetic cardiomyopathy. Heart Fail. Rev., 2014; 19(1): 35-48.

[16] Klachko D, Whaley-Connell A. Use of metformin in patients with kidney and cardiovascular diseases. Cardio. Med., 2011; 1(2): 8795 .
[17] Dumville JC, Deshpande S, O'Meara S, Speak K. Hydrocolloid dressings for healing diabetic foot ulcers. Cochrane Lib. Database Sys. Rev., 2013.

[18] Powers JG, Higham C, Broussard K, Phillips TJ. Wound healing and treating wounds: Chronic wound care and management. $J$. Am. Acad. Dermatol., 2016; 74(4): 607-25.

[19] Simmons CV, Banov F, Banov D. Use of a topical anhydrous silicone base containing fatty acids from pracaxi oil in a patient with a diabetic ulcer. SAGE Open Med. Case Reports., 2015; 3: 2050313 X15589676.

[20] Anderson JL, Halperin JL, Albert NM, Bozkurt B, Brindis RG, Curtis LH, DeMets D, Guyton RA, Hochman JS, Kovacs RJ, Ohman EM. Management of patients with atrial fibrillation (compilation of 2006 ACCF/AHA/ESC and 2011 ACCF/AHA/HRS recommendations): a report of the American College of Cardiology/American Heart Association Task Force on Practice Guidelines. J. Am. Coll. Cardiol., 2013; 61(18): 1935-44.

[21] D'Souza AL, Rajkumar C, Cooke J, Bulpitt CJ. Probiotics in prevention of antibiotic associated diarrhoea: meta-analysis. $B M J$ 2002; 324(7350): 1361.

[22] Pincus M. Management of digoxin toxicity. Aust. Prescr. 2016; 39(1): 18-20.

(C) 2017 National journal of health sciences.

This is an open-access article. 